\title{
Formulasi Krim Ekstrak Daun Kersen (Muntingia calabura L.) Dengan Variasi Kombinasi Span 60 dan Tween 80 Sebagai Emulgator
}

\author{
Metha Anung Anindhita*1, Catur Juni Arsanto ${ }^{2}$ \\ ${ }^{1,2}$ Fakultas Farmasi Universitas Pekalongan \\ Jln. Sriwijaya No.3 Kota Pekalongan Jawa Tengah 51111 \\ e-mail: *19anindhita.m.a@gmail.com
}

Article Info

Article history:

Submission Mei 2020

Accepted Juni 2020

Publish Juli 2020
Ucapan Terima kasih diberikan kepada Fakultas Farmasi Universitas Pekalongan dan Tim Laboran yang telah membantu kelancaran penelitian ini

\begin{abstract}
Abstrak
Ekstrak etanol daun kersen dengan konsentrasi 1,04\% dapat memiliki efektivitas sebagai penyembuh luka bakar. Emulgator dibutuhkan agar stabilitas krim terjaga. span 60 dan tween 80 merupakan emulgator non ionik, bersifat tidak toksik, tidak iritatif, dan memiliki potensi yang rendah menyebabkan reaksi hipersensitivitas. Penelitian ini dilakukan untuk mengetahui pengaruh emulgator terhaadap sifat fisik dan stabilitas fisik krim ekstrak etanol daun kersen serta untuk mendapatkan formula terbaik dari krim tersebut. Penelitian ini dilakukan dengan membandingkan nilai HydrophileLipophile Balances (HLB) dari campuran antara span 60 dan tween 80, yaitu nilai $H L B$ 5; HLB 6,5 dan HLB 8. Pengujian sifat fisik dilakukan dengan menguji organoleptis, homogenitas, $\mathrm{pH}$, viskositas, daya lekat, dan daya sebar. Sedangkan stabilitas fisik dilihat dengan menggunakan metode sentrifugasi. Pengaruh variasi emulgator ditentukan dengan pengujian One Way Anova menggunakan perangkat lunak SPSS. Dikatakan signifikan jika nilai p<0,05. Formula terbaik dilihat dari formula yang memenuhi kriteria pengujian sifat fisik dan yang memiliki stabilitas terbaik. Hasil penelitian menunjukkan perbedaan variasi kombinasi emulgator span 60 dan tween 80 menunjukkan pengaruh pada daya lekat dan $p H$. Formula I dengan nilai HLB 5 menghasilkan formula krim dengan sifat fisik dan stabilitas fisik yang baik.
\end{abstract}

Kata kunci-krim, daun kersen, formulasi, span 60, tween 80 
Keyword - cream, Muntingia calabura L., formulation, span 60, tween 80

DOI $10.30591 /$ pjif.v\%vi\%i.2034

C2020PoliteknikHarapanBersamaTegal

$\begin{array}{lr}\text { Alamat korespondensi: } & \\ \text { Prodi DIII Farmasi Politeknik Harapan Bersama Tegal } & \text { p-ISSN: 2089-5313 } \\ \text { Gedung A Lt.3. Kampus 1 } & \text { e-ISSN: 2549-5062 } \\ \text { Jl. Mataram No.09 Kota Tegal, Kodepos 52122 } & \begin{array}{l}\text { Telp. (0283) 352000 } \\ \text { E-mail: parapemikir_poltek@yahoo.com }\end{array}\end{array}$




\section{A. Pendahuluan}

Pemakaian bahan berkhasiat yang berasal dari alam sudah dipercaya sejak dahulu sebagai upaya penanggulangan masalah kesehatan. Di tengah-tengah kemajuan teknologi dan ilmu pengetahuan saat ini pemanfaatan bahan alam mulai diminati oleh masyarakat. Ekstrak etanol daun kersen dengan dosis 2,6 mg; 5,2 $\mathrm{mg}$ dan 10,4 mg memiliki efek sebagai penyembuh luka bakar dengan prosentase kesembuhan 84,3\%, 85,3\%, dan 93,3\% [1]. Penggunaan ekstrak dalam penyembuhan luka bakar dirasa kurang praktis dan kurang nyaman digunakan sehingga dibutuhkan sediaan dengan konsistensi yang lukan sehingga akan mudah dioleskan tanpa menimbulkan rasa nyeri ketika terkena luka. Bentuk sediaan krim mudah dioleskan pada sediaan kulit dengan luka yang basah dan dapat disebarkan secara merata ${ }^{[2]}$.

Basis cold cream merupakan krim emulsi air dalam minyak dengan kandungan fase minyak yang cukup tinggi, yaitu sebesar $50-85 \%$ [3]. Basis ini dapat memberikan rasa dingin ketika dioleskan dan memiliki data lekat yang baik pada kulit ${ }^{[4]}$ serta dapat digunakan dalam pengobatan luka ${ }^{[5]}$. Stabilitas basis cold cream dapat dijaga dengan menggunakan emulgator sebagai penstabil fase minyak dan fase air di dalam formula [6]. Krim terdiri dari fase minyak dan fase air sama halnya dengan sediaan emulsi. Kestabilan emulsi dapat dicapai dengan menambahkan emulgator tunggal atau kombinasi dengan nilai Hydrophylic-Lipophylic Balance (HLB) yang sesuai nilai HLB tipe krimnya sehingga emulsi dibuat dengan keseimbangan campuran emulgator lipofilik dan hidrofilik.

Span 60 dan tween 80 merupakan emulgator non ionik yang memiliki nilai HLB, bersifat tidak toksik, tidak iritatif, memiliki potensi rendah menyebabkan hipersensitivitas dan stabil terhadap asam lemah dan basa lemah ${ }^{[7]}$. Untuk mendapatkan formula tipe krim air dalam minyak (A/M) dibutuhkan nilai HLB dengan rentang 3-8 ${ }^{[8]}$. Kombinasi emulgator span 60 dan tween 80 mampu membentuk emulsi A/M dengan konsentrasi $10 \%{ }^{[7]}$. Kombinasi yang kurang sesuai antara span 60 dan tween 80 dapat mengakibatkan terbentuknya Phase Invention Temperature (PIT) yang dapat mempengaruhi stabilitas fisik sediaan cold cream selama proses pembuatan dan penyimpanan sediaan ${ }^{[9]}$. Sehingga diperlukan pemilihan kombinasi emulgator untuk mendapatkan nilai HLB yang sesuai untuk mencegah ketidakstabilan dalam emulsi.

Berdasarkan uraian tersebut, peneliti ingin mengetahui pengaruh kombinasi emulgator terhadap sifat fisik dan stabilitas, serta ingin mengetahui kombinasi emulgator yang menghasilkan krim ekstrak etanol daun kersen yang optimal.

\section{B. Metode}

Penelitian ini merupakan penelitian eksperimental yaitu penelitian yang di dalamnya dibuat manipulasi terhadap objek penelitian serta adanya kontrol yang bertujuan untuk menyelidiki ada atau tidaknya sebab akibat dan hubungan anatara sebab akibat tersebut dengan cara memberikan perlakuanperlakuan $^{[10]}$. Varibel dalam penelitian ini meliputi:

Variabel bebas : kombinasi emulgator span 60 dan tween 80 yang menghasilkan nilai HLB 5, HLB 6,5 dan HLB 8.

Variabel terikat : hasil evaluasi sifat fisik sediaan krim yang meliputi organoleptis, homogenitas, $\mathrm{pH}$, daya sebar, daya lekat dan stabilitas fisik sediaan krim.

Variabel terkendali : dosis ekstrak daun kersen dalam formula, konsentrasi vaselin kuning, propilen glikol, metil paraben, propil paraben, dan kondisi percobaan.

\section{Alat}

Timbangan analitik (OHAUS), $\mathrm{pH}$ meter ( $\mathrm{pH}$ 2011 ATC), viskosimeter VT 04 (Rion Japan), Stopwatch, kaca preparat, oven, lemari pendingan, sentrifuse, hot plate stirrer, rotary evaporator, dan peralatan gelas (IWAKI),

\section{Bahan}

Daun kersen (dari desa Talun Kabupaten Pekalongan, Jawa Tengah), tween 80, span 60, propilen glikol, metil paraben, vaselin flavum, etanol 96\%, dan aquadest yang semuanya berasal dari Brataco.

\section{Jalannya penelitian}

\section{Pembuatan ekstrak daun kersen}

Daun kersen yang digunakan adalah daun kersen yang berwarna hijau tua dan segar ${ }^{[11]}$ dikeringkan dengan cara diangin-anginkan dan terlindung dari sinar matahari, kemudian di blender dan disimpan didalam wadah kaca, tertutup rapat, terlindung dari sinar matahari,s erta disimpan pada suhu $\operatorname{kamar}^{[1]}$.

Ekstraksi dilakukan menggunakan metode remaserasi dengan pelarut etanol $70 \%$ sebanyak 2 L. sejumlah 150 gram serbuk 
kering daun kersen dimasukkan dalam wadah kaca, direnda, dengan pelarut etanol $70 \%$ selama 24 jam dan dilakukan pengadukan tiap 1 jam. Setiap 24 jam maserat disaring dengan kain flannel dan ampas ditambah cairan penyari lagi dengan jumlah yang sama. Maserasi dilakukan berulang hingga mencapai titik akhir maserasi dimana cairan pelarut yang digunakan tidak berwarna lagi. Maserat yang diperoleh kemudian dicampur sampai homogen dan diuapkan di atas waterbath sampai diperoleh ekstrak yang kental ${ }^{[1]}$.

2. Formulasi krim ekstrak daun kersen

Pemilihan formula dalam penelitian ini merujuk pada penelitian Gotaro $^{[12]}$.

Tabel 1. Formulasi krim ekstrak daun kersen

\begin{tabular}{|c|c|c|c|}
\hline \multirow[b]{2}{*}{ Bahan } & \multicolumn{3}{|c|}{ Konsentrasi Bahan (\%) } \\
\hline & $\begin{array}{c}\text { Formula } \\
\text { I } \\
\text { (HLB 5) }\end{array}$ & $\begin{array}{c}\text { Formula } \\
\text { II } \\
(\mathrm{HLB} \\
6,5)\end{array}$ & $\begin{array}{c}\text { Formula } \\
\text { III } \\
\text { (HLB 8) }\end{array}$ \\
\hline $\begin{array}{l}\text { Ekstrak daun } \\
\text { kersen }\end{array}$ & 1,04 & 1,04 & 1,04 \\
\hline Vaselin & 55 & 55 & 55 \\
\hline kuning & 20 & 20 & 20 \\
\hline Propilen & 0,3 & 1,75 & 3,2 \\
\hline glikol & 9,7 & 8,25 & 6,8 \\
\hline Tween 80 & 0,25 & 0,25 & 0,25 \\
\hline Span 60 & 0,1 & 0,1 & 0,1 \\
\hline $\begin{array}{l}\text { Metil paraben } \\
\text { Propil paraben } \\
\text { Akuades }\end{array}$ & Ad 100 & Ad 100 & Ad 100 \\
\hline
\end{tabular}

\section{Pembuatan sediaan krim ekstrak daun kersen}

Basis krim yang digunakan adalah basis cold cream. Pembuatan cold cream dilakukan dengan melakukan pencampuran dan pemanasan vaselin kuning, span 60 menggunakan waterath pada suhu $70^{\circ} \mathrm{C}$ hingga meleleh sempurna, kemudian ditambahkan propil paraben (fase minyak). Ke dalam campuran fase minyak ditambahkan campuran fase air berupa tween 80, metil paraben, propilen glikol dan air yang sudah dipanaskan pada suhu $70^{\circ} \mathrm{C}$. Fase air dimasukkan ke dalam fase minyak dan diaduk dengan menggunakan magnetic stirrer selama 4 menit. Setelah basis cold cream terbentuk diambkan hingga suhu turun menjadi $40^{\circ} \mathrm{C}$, kemudian ekstrak daun kersen dimasukkan dalam basis tersebut, aduk konstan selama 4 menit $^{[13]}$.

\section{Uji sifat fisik sediaan krim \\ a. Organoleptis}

Pengujian organoleptis yang dilakukan meliputi pengamatan warna, aroma, dan tekstur sediaan krim. Pengujian dilakukan pada 10 panelis dengan kriteria antara lain, tidak terlatih, usia dewasa, dan sehat fisik. Kriteria organoleptis yang baik untuk sediaan krim adalah lembut, warna dan aroma krim sesuai dengan ekstrak yang digunakan ${ }^{[14]}$.

\section{b. Homogenitas}

Homogenitas sediaan krim diuji dengan cara sejumlah krim diambil dari bagian atas, tengah dan bawah, kemudian dioleskan pada kaca obyek. Krim dikatakan homogen jika saat dioleskan pada sekeping kaca tidak ada pemisahan antara komponen penyusun krim tersebut ${ }^{[14]}$.

\section{c. $\mathbf{p H}$}

Pemeriksaan keasaman $(\mathrm{pH})$ pada sediaan krim menggunakan $\mathrm{pH}$ meter. Kalibrasi dilakukan dengan menggunakan larutan dapar standar $\mathrm{pH} 4$ (asam) dan $\mathrm{pH} 7$ (basa). Pengukuran dilakukan dengan mencelupkan elektroda dalam sediaan krim pada suhu ruang. Sediaan topikal yang baik memiliki nilai $\mathrm{pH}$ antara 4,5-7,0 yang merupakan rentang nilai $\mathrm{pH}$ kulit sehingga tidak akan menimbulkan iritasi ${ }^{[15]}$.

\section{d. Viskositas}

Viskositas sediaan krim diukur dengan menggunakan Viskosimeter VT-04 (Rion, Japan). Cara menggunakannya adalah dengan memasukkan sediaan ke dalam wadah tabung, pasang rotor no. 1, pastikan rotor terendam dalam sediaan yang akan diuji. Nyalakan viskosimeter VT-04 dan amati jarum penunjuk viskosimeter mengarah ke angka pada skala viskositas untuk rotor no. 1. Saat jarum menunjukkan ke angka yang stabil maka angka itulah yang merupakan viskositas yang diukur, catat dalam satuan $\mathrm{dPaS}^{[13]}$. Standar viskositas krim yang ideal yaitu tidak kurang dari $50 \mathrm{dPas}^{[16]}$.

\section{e. Daya lekat}

Uji ini dilakukan dengan menggunakan alat uji daya lekat, yaitu dua gelas objek, stopwatch, dan anak timbangan (gram). Uji dilakukan dengan meletakkan 0,5 gram krim pada geas objek dan ditutup dengan gelas objek lain diatasnya, kemudian ditekan dengan beban $1 \mathrm{~kg}$ selama 5 menit, setelah itu gelas 
objek dipasang pada alat dengan beban 80 gram dan catat waktu hingga kedua gelas objek tersebut terlepas. Kriteria waktu daya lekat yang baik untuk sediaan topikal adalah tidak kurang dari 4 detik ${ }^{[17]}$.

\section{f. Daya sebar}

Uji ini dilakukan dengan menimbang 0,5 gram krim dan diletakkan ditengan cawan petri. Letakkan cawan petri yang lain di atas krim tersebut (cawan petri sudah ditimbang). Lakukan pengukuran berapa diameter krim yang menyebar, kemudian ditambahkan beban 50 gram, diamkan 1 menit dan catat kembali diameternya dan diteruskan dengan menambah beban 50 gram tiap sekali penambahan hingga beban 250 gram. Kriteria diameter daya sebar yang baik untuk sediaan topikal sekitar 5-7 cm ${ }^{[17]}$.

\section{g. Iritasi kulit}

Uji ini dilakukan dengan menimbang sebanyak 0,1 gram krim, dioleskan pada kulit lengan bagian dalam dengan ukuran $2 \times 2 \mathrm{~cm}$ kemudian ditutup dengan kain kasa dan plester. Setelah itu dilihat gejala yang ditimbulkan setelah 24 jam pemakaian. Uji ini dilakukan untuk masing-masing formula dengan 6 orang panelis. Dikatakan tidak menimbulkan iritasi jika setelah pemakaian 24 jam tidak timbul rasa gatal ataupun kemerahan $^{[18]}$.

\section{Uji stabilitas fisik krim}

Uji stabilitas dilakukan dengan metode sentrifugasi. Sebanyak 10 gram krim dimasukkan ke dalam tabung sentrifugasi kemudian dilakukan sentrifugasi pada suhu ruang dengan kecepatan $3800 \mathrm{rpm}$ selama 5 jam. Sistem emulsi yang stabil menunjukkan tidak terjadinya pemisahan fase setelah disentrifugasi. Kecepatan $3800 \mathrm{rpm}$ mengindikasikan bahwa sediaan stabil selama 1 tahun pada suhu ruang. Krim dinyatakan stabil jika tidak terjadi pemisahan fase setelag perlakuan sentrifugasi ${ }^{[19]}$.

\section{Analisis Data}

Data nilai $\mathrm{pH}$, viskositas, daya lekat, dan daya sebar dari pengujian sifat fisik tiap formula dianalisis dengan menggunakan perangkat lunak SPSS menggunakan uji One Way Anova. Dari pengujian statistik dengan menggunakan SPSS dihasilkan kesimpulan berbeda bermakna jika nilai signifikansi lebih kecil dari 0,05 dan dinyatakan tidak berbeda bermakna jika nilai signifikansi lebih besar 0,05 . Formula krim ekstrak etanol daun kersen
}

yang optimal diperoleh dari hasil terbaik pengujian sifat fisik dan stabilitas fisik.

\section{Hasil Dan Pembahasan}

Ekstraksi daun kersen dengan metode remaserasi menghasilkan rendemen 26,22\%. Tidak terciumnya lagi bau khas etanol menunjukkan bahwa ekstrak sudah terbebas dari pelarut etanol. Hasil ekstraksi dapat dilihat pada gambar 1 .

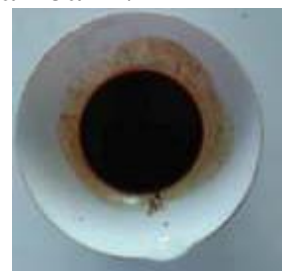

Gambar 1. Hasil ekstrasi daun kersen

Krim dibuat dalam 3 formula dengan variasi kombinasi emulgator yang menghasilka nilai HLB yang berbeda, yaitu HLB 5, HLB 6,5 dan HLB 8. Hasil formulasi menunjukkan sediaan yang berana kuninh kecoklatan dan memiliki aroma khas eksrak daun kersen. Span 60 dapat digunakan sebagai emulgator krim tipe M/A atau A/M bersama dengan tween. Krim dengan span 60 memiliki tekstur yang halus dan stabil, sedangkan tween 80 biasa digunakan sebagai dengan konsentrasi $1-15 \%$, dapat membentuk krim tipe M/A dengan tekstur yang halus dan berguna dalam pembuatan krim yang larut dalam air dan mudah tercuci dengan air. Kombinasi span 60 dan tween 80 dapat digunakan sebagai emulgator krim tipe $\mathrm{A} / \mathrm{M}$ dalam konsentrasi $10 \%{ }^{[7]}$.

Bahan tambahan lain dalam krim yaitu vaselin flavum dapat berfungsi sebagai basis dan emolien[7]. Formula krim ekstrak etanol daun kersen (Muntingia calabura L.) menggunakan vaselin flavum sebanyak 55 $\%^{[12]}$. Propilen glikol digunakan secara luas dalam kosmetik dan industri farmasi sebagai pelarut dan pembawa untuk bahan-bahan yang larut dan tidak larut dalam air. Propilen glikol dalam sediaan krim digunakan sebagai humektan atau pelembab dengan konsentrasi $5-20 \%{ }^{[8]}$. Methyl paraben dan propyl paraben berfungsi sebagai zat pengawet karena sediaan krim memiliki kandungan air yang tinggi yang dapat menyebabkan kontaminasi mikroba. Konsentrasi pengawet yang digunakan adalah propyl paraben $0,02 \%$ dan methyl paraben $0,18 \%$. Sedangkan akuades 
dalam formula digunakan sebagai pelarut sediaan krim $^{[7]}$.

\section{Hasil uji sifat fisik sediaan krim ekstrak etanol daun kersen}

Penentuan formula terbaik dilakukan melalui pengujian sifat fisik dan stabilitas. Pengujian yang dilakukan meliputi uji organoleptis, homogenitas, viskositas, daya lekat, daya sebar dan uji iritasi. Hasil uji fisik dan uji stabilitas sediaan krim ekstrak etanol daun kersen dapat dilihat pada tabel 2.

\section{a. Organoleptis}

Uji organoleptis yang dilakukan meliputi pengujian warna, aroma dan tekstur sediaan krim. Sediaan krim ekstrak etanol daun kersen dapat dilihat pada gambar 2, sedangkan hasul pengujian organoleptis krim ekstrak daun kersen dapat dilihat pada tabel 2 .

Warna kuning kecoklatan pada sediaan merupakan perpaduan warna ekstrak daun kersen yang berwarna coklat kehitaman dengan vaselin flavum. Sediaan memiliki aroma menyerupai ekstrak daun kersen yang lemah, karena kandungan ekstrak dalam sediaan tidak terlalu besar, yaitu 1,04\%. Ketiganya memiliki struktur yang lembut karena menggunakan emulgator span 60 dan tween 80 yang dapat menghasilkan krim yang halus dan lembut ${ }^{[7]}$.

Krim dengan konsistensi lembut, serta warna dan bau krim sesuai dengan ekstrak tanaman yang digunakan merupakan syarat dari bentuk sediaan krim. Meskipun masingmasing formula memiliki konsentrasi emulgator yang berbeda, namun karena ekstrak yang digunakan dalam ketiga formula konsentrasinya sama dan hanya sebesar 1,04
$\%$, maka tidak terlalu berpengaruh terhadap organoleptis sediaan. Dari hasil penilaian yang telah diberikan oleh panelis pada tiap formula dan replikasi 3 kali ini, dapat disimpulkan bahwa ketiga formula krim memenuhi syarat organoleptis, serta dapat diketahui bahwa perbedaan konsentrasi emulgator pada masing-masing formula tidak memberikan perbedaan terhadap organoleptis sediaan krim.

\section{b. Homogenitas}

Uji homogenitas bertujuan untuk mengetahuai bahwa semua bahan sudah tercampur secara merata ${ }^{[20]}$. Hasil uji homogenitas dapat dilihat pada tabel 2. Hasil pengujian menunjukkan tidak ada partikelpartikel yang menggumpal pada kaca objek. Hal tersebut sesuai dengan persyaratan dimana suatu sediaan harus menunjukkan susunan yang homogen dan tidak terlihat adanya partikel yang menggumpal.

Pengujian $\mathrm{pH}$ dilakukan karena sediaan yang dibuat adalah krim yang digunakan secara topikal, dan kulit sangat sensitif terhadap $\mathrm{pH}$. Uji $\mathrm{pH}$ bertujuan untuk mengetahui nilai $\mathrm{pH}$ pada sediaan krim masih dalam rentang $\mathrm{pH}$ normal kulit atau tidak. Rentang $\mathrm{pH}$ normal kulit yaitu berkisar antara 4,5-7,0. Jika $\mathrm{pH}$ terlalu asam maka dapat menimbulkan iritasi pada kulit dan jika $\mathrm{pH}$ terlalu basa maka dapat menimbulkan kulit bersisik[15]. Pengujian $\mathrm{pH}$ dilakukan dengan menggunakan $\mathrm{pH}$ meter yang sebelumnya sudah dilakukan kalibrasi terlebih dahulu. Hasil dari pengamatan $\mathrm{pH}$ dapat dilihat pada tabel 2.
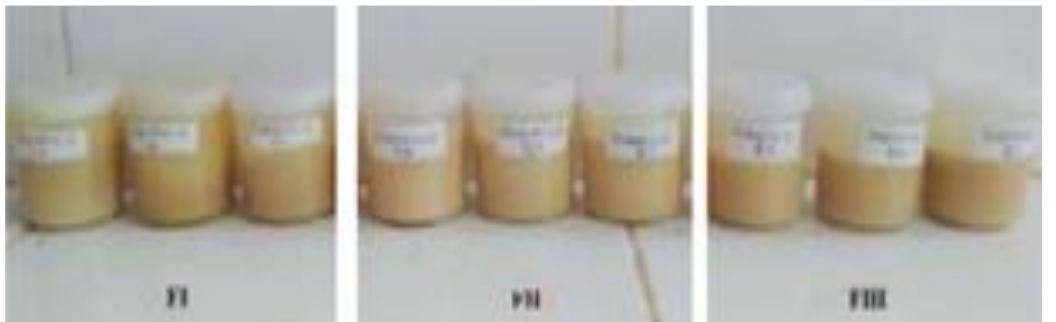

Gambar 2. Sediaan krim ekstrak daun kersen

Tabel 2. Hasil uji sifat fisik sediaan krim ekstrak daun kersen

\begin{tabular}{lccc}
\hline \multirow{2}{*}{ Pengujian } & \multicolumn{3}{c}{ Formula (rerata \pm SD) } \\
\cline { 2 - 4 } & F I (HLB 5) & F II (HLB 6,5) & F III (HLB 8) \\
\hline a. Organoleptis & Kuning & Kuning & Kuning \\
Warna & kecoklatan & kecoklatan & kecoklatan \\
\hline
\end{tabular}






Berdasarkan uji viskositas formula III memiliki viskositas paling kecil jika dibandingkan dengan ke-2 formula lainnya, sehingga formula III paling mudah dalam pengolesan. Ketiga formula memenuhi kriteria viskositas krim yang baik yaitu tidak kurang dari $50 \mathrm{dPas}^{[16]}$.Viskositas sendiri berkaitan dengan daya lekat dan daya sebar sediaan krim $^{[22]}$.

Hasil uji homogenitas data dapat disimpulkan bahwa varian ketiga data terdistribusi normal, dengan2 nilai signifikasi>0,05 $\quad(0,198>0,05) . \quad$ Kemudian dilakukan analisis dengan metode One Way Anova untuk mengetahui adanya pengaruh variasi nilai HLB terhadap viskositas krim ekstrak etanol daun kersen (Muntingia calabura L.). Hasil uji Anova menunjukkan bahwa nilai signifikasi lebih besar dari 0,05 $(0,098>0,05)$ maka dapat disimpulkan bahwa tidak terdapat pengaruh variasi nilai HLB terhadap viskositas sediaan krim ekstrak etanol daun kersen (Muntingia calabura L.). Namun, dari hasil pengujian viskositas tersebut dapat diketahui dimana semakin kecil nilai HLB yang digunakan maka semakin tinggi viskositas sediaan krim yang dihasilkan meskipun perbedaannya tidak terlalu besar. Komponen span 60 lebih dominan berpengaruh meningkatkan viskositas 
dikarenakan sifat kimia dari span 60 yang lipofilik cenderung mengikat fase minyak yang lebih dominan pada krim tipe $\mathrm{A} / \mathrm{M}$ sehingga pembentukan emulsi lebih baik saat jumlah span 60 lebih banyak. Hal tersebut menyebabkan emulsi lebih berminyak dan viskositas lebih tinggi dikarenakan fase air yang terikat didalam minyak ${ }^{[12]}$.

\section{d. Daya lekat}

Uji daya lekat bertujuan untuk mengetahui kemampuan krim melekat pada kulit. Semakin lama krim melekat pada permukaan kulit maka krim tersebut semakin baik, hal ini dapat dijelaskan bahwa semakin lama krim melekat maka daya absorbsi obat akan semakin besar karena ikatan yang terjadi antara krim dengan kulit semakin lama, sehingga basis dapat melepaskan obat lebih optimal. Namun apabila daya lekatnya terlalu lemah, maka absorbs obat akan kurang optimal sehingga efek terapi tidak tercapai ${ }^{[20]}$. Hasil pengamatan daya lekat sediaan krim dapat dilihat pada tabel 2 .

Berdasarkan uji daya lekat dapat dilihat bahwa formula I memiliki daya lekat lebih tinggi jika dibandingkan dengan ke-2 formula lainnya, sehingga formula I memiliki daya absorbsi yang lebih besar. Dari data daya lekat tersebut dapat diketahui bahwa semakin kecil nilai HLB akan mempengaruhi daya lekat sediaan krim yaitu akan semakin lama waktu daya lekatnya. Pada dasarnya ketiga formula memenuhi kriteria daya lekat krim yang baik yaitu tidak kurang dari 4 detik ${ }^{[16]}$. Daya lekat berkaitan dengan viskositas, dimana semakin tinggi viskositas suatu sediaan krim maka daya melekatnya semakin tinggi ${ }^{[22]}$. Seperti yang telah dijelaskan pada uji viskositas bahwa komponen span 60 lebih dominan berpengaruh meningkatkan viskositas, sehingga juga berpengaruh dalam meningkatkan daya lekat krim. Formula I dengan HLB paling kecil mengandung span 60 lebih banyak daripada kandungan span 60 pada formula II dan formula III, maka daya lekatnya cenderung lebih lama.

Data yang diperoleh dari uji daya lekat selanjutnya dilakukan uji homogenitas menggunakan perangkat lunak SPSS yang menunjukkan data terdistribusi normal, dengan nilai signifikasi lebih besar dari 0,05 $(0,051>0,05)$ 0,051. Berdasarkan hasil uji Anova bahwa nilai signifikasi lebih kecil dari $0,05 \quad(0,018<0,05) \quad$ menunjukkan bahwa terdapat pengaruh variasi nilai HLB terhadap daya lekat sediaan krim ekstrak etanol daun kersen (Muntingia calabura L.). kemudian dari pengujian Post Hoc Test memperlihatkan bahwa formula yang menunjukkan perbedaan bermakna adalah pada formula I dan formula III.

\section{e. Daya sebar}

Uji daya sebar sediaan krim dilakukan untuk mengetahui kualitas krim yang dapat menyebar pada kulit dan dengan cepat pula memberikan efek terapinya. Daya sebar yang baik dapat menjamin pelepasan bahan obat yang memuaskan ${ }^{[23]}$. Luas penyebaran berbanding lurus dengan kenaikan beban yang ditambahkan, semakin besar beban yang ditambahkan maka penyebaran semakin luas. Suatu sediaan krim diharapkan mampu menyebar dengan mudah ditempat pemberian, semakin mudah dioleskan maka luas permukaan kontak obat dengan kulit semakin besar. Sehingga absorbsi obat ditempat pemberian semakin optimal. Permukaan penyebaran yang dihasilkan dengan peningkatan beban yang ditambahkan merupakan karakteristik daya sebar krim. Hasil pengamatan daya sebar dapat dilihat pada tabel 2

Hasil pengamatan daya sebar pada ketiga formula dapat diketahui bahwa terjadi perluasan penyebaran krim setiap kali penambahan beban, hal ini menunjukkan bahwa ketiga formula sediaan krim memiliki kemampuan menyebar secara merata. Formula III memiliki daya sebar lebih besar dibandingkan dengan formula I dan II. Sehingga dapat diketahui bahwa formula III dengan nilai HLB 8 menghasilkan sediaan krim dengan daya sebar paling baik.

Data yang diperoleh selanjutnya dilakukan uji homogenitas dengan menggunakan perangkat lunak SPSS, diketahui ketiga formula terdistribusi normal yaitu nilai signifikansinya lebih besar dari 0,05 $(0,121>0,05)$.

Selanjutnya data di uji dengan One Way Anova untuk mengetahui adanya pengaruh penggunaan variasi HLB terhadap daya sebar sediaan krim ekstrak etanol daun kersen (Muntingia calabura L.). Berdasarkan hasil uji Anova bahwa signifikasi lebih besar dari $0,05(0,269>0,05)$ maka dapat disimpulkan bahwa tidak terdapat pengaruh dalam penggunaan variasi nilai HLB terhadap daya 
sebar sediaan krim ekstrak etanol daun kersen (Muntingia calabura L.). Namun, hasil daya sebar yang diperoleh tersebut menunjukkan bahwa sediaan krim yang dibuat telah memenuhi syarat dimana diameter daya sebar 5-7 cm menunjukkan konsisntensi semisolid yang sangat nyaman dalam penggunaan ${ }^{[22]}$. Daya sebar yang baik menyebabkan kontak antara obat dengan kulit menjadi luas, sehingga absorbsi obat ke kulit berlangsung cepat $^{[23]}$.

Emulgator span 60 dan tween 80 berpengaruh dalam meningkatkan daya sebar pada setiap formula. Peningkatan daya sebar krim lebih dominan disebabkan adanya tween 80 , dikarenakan tween 80 yang bersifat hidrofilik akan mengikat fase air, pada formula yang

memiliki jumlah tween 80 yang lebih banyak akan membuat fase air tidak terikat sempurna oleh fase minyak sehingga viskositas menurun dan daya sebar menjadi meningkat [12]. Dalam formula III mengandung tween 80 lebih banyak daripada formula I dan formula II, maka daya sebar formula III lebih luas.

\section{f. Iritasi}

Uji iritasi sediaan krim dilakukan untuk mengetahui sediaan krim yang dibuat dapat menyebabkan gatal, kemerahan dan pengkasaran pada kulit atau tidak. Krim dioleskan pada kulit lengan bagian dalam dengan ukuran $2 \times 2 \mathrm{~cm}$, kemudian ditutupi dengan kain kasa dan plester. Setelah itu dilihat gejala yang ditimbulkan setelah 24 jam pemakaian. Hasil dari uji iritasi sediaan krim dapat dilihat pada tabel 2 .

Uji iritasi yang dilakukan terhadap kulit sukarelawan diperoleh hasil yaitu tidak ada terlihat efek samping berupa kemerahan, gatal dan pengkasaran pada kulit yang ditimbulkan oleh sediaan krim ekstrak etanol daun kersen (Muntingia calabura L.). Iritasi dapat disebabkan oleh kandungan ekstrak atau bahan lain dalam sediaan. Bahan-bahan dari formula krim ekstrak etanol daun kersen antara lain span 60 dan tween 80 merupakan emulgator yang bersifat tidak toksik, tidak iritatif, memiliki potensi yang rendah untuk menyebabkan reaksi hipersensitivitas [7]. Vaselin flavum biasa digunakan pada sediaan topikal sebagai basis dan emolien. Propilenglikol digunakan secara luas dalam kosmetik dan industri farmasi, dalam sediaan krim digunakan sebagai humektan atau pelembab dengan konsentrasi 5-20 \% ${ }^{[8]}$. Methil paraben dan propil paraben merupakan pengawet yang biasa digunakan dalam sediaan topikal. Dari uraian bahan-bahan tersebut dapat diketahui bahwa formula krim ekstrak etanol daun kersen tidak mengandung bahan yang bersifat iritatif sehingga dapat disimpulkan bahwa sediaan krim ekstrak etanol daun kersen (Muntingia calabura L.) yang dibuat aman untuk digunakan pada kulit. Pengujian iritasi sediaan krim ekstrak etanol daun kersen dapat dilihat pada gambar 3 .

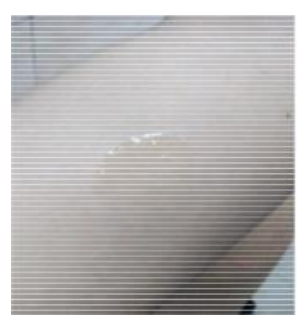

A

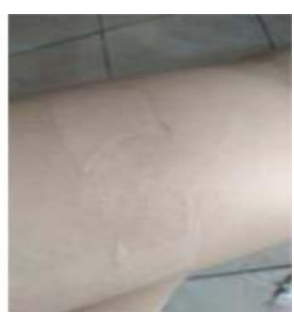

B
Gambar 3. Uji iritasi sebelum 24 jam pemakaian (A) dan setelah 24 jam pemakaian (B)

\section{g. Stabilitas Fisik}

Evaluasi stabilitas krim dilakukan dengan uji mekanik yaitu dengan metode sentrifugasi. Uji mekanik dimaksudkan untuk melihat kestabilan krim setelah pengocokan dengan kecepatan tinggi. Ketiga formula krim disentrifugasi dengan kecepatan putaran 3800 rpm selang waktu 30 menit selama 5 jam pada suhu ruang karena hasilnya ekivalen dengan efek grafitasi selama 1 tahun ${ }^{[24]}$. Setelah disentrifugasi, diamati apakah terjadi pemisahan fase atau tidak antara fase air dengan fase minyak. Hasil yang diperoleh dari uji sentrifugasi dapat dilihat pada tabel 2 .

Hasil uji stabilitas fisik metode sentrifugasi menunjukkan ketiga formula mengalami pemisahan fase setelah dilakukan sentrifugasi dalam waktu kurang dari 5 jam atau 10 siklus (satu siklus uji sentrifugasi $=30$ menit). Hasil uji sentrifugasi tersebut menunjukkan bahwa sediaan krim ekstrak etanol daun kersen (Muntingia calabura L.) formula I stabil pada uji sentrifugasi selama 3 siklus (90 menit), formula II dan formula III stabil pada uji sentrifugasi selama 2 siklus (60 menit).

Formula I adalah formula yang memiliki stabilitas paling baik diantara formula lainnya karena pemisahan fase saat uji sentrifugasi 
terjadi dalam waktu paling lama yaitu sama dengan stabil selama 3,6 bulan. Satu siklus pengujian sentrifugasi sama dengan sediaan krim stabil selama 1,2 bulan, diperoleh dari perhitungan 12 bulan/10 siklus.

\section{Pemilihan formula terbaik}

Hasil pengujian sifat fisik dan stabilitas fisik krim ekstrak etanol daun kersen digunakan untuk menentukan formula terbaik dari 3 formula yang dibuat. Dapat diketahui bahwa formula I, formula II dan formula III memenuhi syarat dari uji sifat fisik (uji organoleptis, uji homogenitas, uji $\mathrm{pH}$, uji daya lekat, uji viskositas, uji $\mathrm{pH}$ dan uji iritasi. Sedangkan untuk pengujian stabilitas fisik krim ketiga formula terjadi pemisahan fase dengan hasil formula I lebih stabil dari formula II dan III.

Krim ekstrak etanol daun kersen diindikasikan untuk pengobatan luka bakar karena kandungan kimia pada daun kersen efektif digunakan sebagai penyembuhan luka bakar. Untuk pengobatan luka bakar diperlukan sediaan yang memiliki daya lekat baik sehingga absorbsi zat aktif akan lebih besar karena ikatan yang terjadi antara krim dengan kulit semakin lama, sehingga basis dapat melepaskan obat lebih optimal ${ }^{[20]}$. Dari hasil pengujian sifat fisik dan stabilitas fisik krim, dapat diketahui bahwa formula I menghasilkan waktu daya lekat dan stabilitas fisik paling lama dibandingkan formula II dan III. Maka, dapat disimpulkan bahwa formula I krim ekstrak etanol daun kersen (Muntingia calabura L.) basis cold cream dengan nilai HLB 5 dipilih sebagai formula paling optimal.

\section{Simpulan}

Perbedaan variasi kombinasi span 60 dan tween 80 sebagai emulgator menghasilkan nilai HLB yang berbeda dan berpengaruh terhadap $\mathrm{pH}$, daya lekat dan stabilitas dari sediaan krim ekstrak daun kersen. Formula I krim ekstrak etanol daun kersen (Muntingia calabura L.) dengan nilai HLB 5 merupakan formula yang paling optimal.

\section{Pustaka}

[1] Handayani, Fitri \& Triswanto Sentat., 2016, Uji Aktivitas Ekstrak Etanol Daun Kersen (Muntingia calabura L.) Terhadap Penyembuhan Luka Bakar Pada Kulit Mencit Putih Jantan (Mus musculus), Jurnal Ilmiah Ibnu Sina,
Akademi Farmasi Samarinda, Samarinda

[2] Wijaya, R.A., 2013, Formulasi Krim Ekstrak Lidah Buaya (Aloe vera) sebagai alternative Penyembuhan Luka Bakar, Skripsi, Fakultas Matematika dan Ilmu Pengetahuan Alam, Universitas Negri Semarang, Semarang

[3] Mitzui, T., 1997, New Cosmetic Science. Amsterdam. Elsevier Science B. V, 342, Amsterdam

[4] Arisanti, C. I., Indraswari, P. I. Budiputra, D. K., 2016, Pengaruh Komposisi Span 80 dan Cera Alba Terhadap Stabilitas Fisik Sediaan Cold Cream Ekstrak Etanol 96\% Kulit Buah Manggis (Garcinia mangostana L.), Jurnal Farmasi, Universitas Udayana, Bali

[5] Ansel, H. C., 1989, Pengantar Bentuk Sediaan Farmasi, Edisi IV, Universitas Indonesia, Jakarta

[6] Barel, A. O., Paye.M., Maibach.H. I., 2009, Handbook of Cosmetic Science and Technology, 3rd Edition, 122-132, Informa Healthcare USA, New York

[7] Rowe, R., Sheskey, P., \& Quinn, M., 2009, Handbook of Pharmaceutical Excipients, 6th, 155-156, Pharmaceutical Press and American Pharmacists Association, USA

[8] Martin, A., S. James \& C. Arthur., 2008, Farmasi Fisik, Universitas Indonesia, Jakarta

[9] Lachman, L., Lieberman, H., \& Kanig, J., 1994, Teori dan Praktek Farmasi Industri II, Edisi 3, diterjemahkan oleh Suyatmi, S., 1117, Indonesia University Press, Jakarta

[10] Sugiyono, 2013, Metode Penelitian Kuantitatif Kualitatif dan R \& D, Alfabeta, Bandung

[11] Haki M., 2009, Efek Ekstrak Daun Talok (Muntingia Calabura L.) terhadap Aktivitas Enzim SGPT pada Mencit yang diinduksi Karbon Tetraklorida, Skripsi, Fakultas Kedokteran Universitas Sebelas Maret, Surakarta

[12] Gotaro, D. R., 2016, Optimasi Komposisi Emulgator Span 60 dan Tween 80 Terhadap Stabilitas Fisik Sediaan Cold Cream Ekstrak Etanol Pelepah Pisang Ambon Kuning (Musa 
paradisiacal L.), Skripsi, Universitas Sanatha Dharma, Yogyakarta

[13] Shovyana, H.H. dan Zulkarnain, A.K., 2013, Stabilitas Fisik dan Aktivitas Krim W/O Ekstrak Buah Mahkota Dewa (Phaleria macrocarpha (scheff.) Boerl,) Sebagai Tabir Surya, 109-117, Jurnal Traditional Medicine, Universitas Gadjah Mada, Yogyakarta

[14] Juwita, A. P., Yamlean P., Edy H. J., 2013, Formulasi Krim Ekstrak Etanol Daun Lamun (Syringodium isoetifolium), Skripsi, Universitas Sam Ratulangi, Samarinda

[15] Kurniati, N., 2011, Uji Stabilitas Fisik dan Antioksidan Formula Krim Mengandung Ekstrak Kulit Buah Delima (Punica granantum L.), Skripsi, Fakultas Matematika dan Ilmu Pengetahuan Alam, Program Sarjana Farmasi, Universitas Indonesia, Depok

[16] Hanani, Endang., 2016, Analisis Fitokimia, 103-109, 227-234, 79-84, Buku Kedokteran EGC, Jakarta

[17] Ulaen, S. P.J., Banne, Yos Suatan \& Ririn A., 2012, Pembuatan Salep Anti Jerawat dari Ekstrak Rimpang Temulawak (Curcuma xanthorrhiza Roxb.), 45-49, Jurnal Ilmiah Farmasi, Jurusan Farmasi Politeknik Kesehatan Kemenkes, Manado

[18] Suhery, W.N., Armon Fernando, Netralis Has, 2016, Uji Aktivitas Antioksidan Dari Ekstrak Bekatul Padi Ketan Merah Dan Hitam (Oryza sativa L. var. glutinosa) Dan Formulasinya Dalam Sediaan Krim, Skripsi, Sekolah Tinggi Ilmu Farmasi, Riau

[19] Hamsinah., Darijanto, D.A., Mauludin Rachmad., 2016, Uji Stabilitas Formulasi Krim Tabir Surya Serbuk Rumput Laut (Eucheuma cottoni. Doty), Jurnal Farmasi Umi, Fakultas Farmasi, Institut Teknologi Bandung, Bandung

[20] Manurung, D. M., 2012, Formulasi Krim Tipe M/A dan A/M Repelan Minyak Atsiri Akar Wangi (Vetiveria zizanioidesi (L) Nash) dengan Evalausi Sifat Fisisnya, Skripsi, Universitas Sebelas maret, Surakarta

[21] Putri, V.S., 2013, Formulasi Krim Ekstrak Etanol Herba Pegagan (Centella asiatica (L.) Urban) Konsentrasi 6\% Dan 10\% Dengan Basis Cold Cream dan Vanishing Cream Serta Uji Aktivitas Antibakteri Terhadap Staphylococcus aureus, Skripsi, Universitas Muhammadiyah Surakarta, Surakarta

[22] Syamsuni, H.A., 2006, Ilmu Resep, Cetakan I, 124, Penerbit Buku Kedokteran, Jakarta

[23] Voigt, R., 1994, Buku Pelajaran Teknologi Farmasi. terjemahan oleh Soewandi, S.N, Gadjah Mada University Press, Yogyakarta

[24] Garg, A.A., Deepika, A., Sanjay, G., dan Anil, K.S., 2002, Spreading of Semisolid Formulation : An Update, Pharmaceutical Technology, USA

[25] Hamsinah., Darijanto, D.A., Mauludin Rachmad., 2016, Uji Stabilitas Formulasi Krim Tabir Surya Serbuk Rumput Laut (Eucheuma cottoni. Doty), Jurnal Farmasi Umi, Fakultas Farmasi, Institut Teknologi Bandung, Bandung 